\title{
Work- and family-related variables, work-family conflict and women's well-being: some observations
}

\author{
NORAINI M. NOOR
}

Department of Psychology, International Islamic University, Kuala Lumpur, Malaysia

\begin{abstract}
The present study was carried out to test an exploratory model consisting of three sets of variables (demographic, personality and work- and family-related variables) in the prediction of well-being. The model also provided a test of the indirect effect of these variables on well-being, via perceptions of work-family conflict. Both quantitative and qualitative analyses were used. In a sample of 147 employed British women with children, the results showed that these three sets of variables had both direct and indirect influence on well-being. Although work-related variables explained the most variance in the prediction of workinterfering-with-family conflict and job satisfaction, personality variables accounted for the most variance in the prediction of family-interfering-with-work conflict. Similarly, in the prediction of distress symptoms, demographic variables accounted for the most variance. The qualitative responses provided by the women complemented these findings. The proposed model appears to provide a better fit of the complex relationships that may exist between the many variables encompassing women's work and family lives than previous ones that have considered only one set of variables.
\end{abstract}

KEY WORDS Work and family-related variables; work-family conflict; well-being; personality; job satisfaction; distress

RESUMEN La présente étude a été effectuée pour examiner un modèle exploratoire se composant de trois ensembles de variables (démographiques, personnalité et travail et variables relatives de famille) dans la prévision du bien-être. Le modèle a également fourni un essai de l'effet indirect de ces variables sur le bien-être, par l'intermédiare des perceptions de conflit de travailler-famille. Des analyses quantitatives et qualitative ont été employées. Dans un échantillon de 147 a employé les femmes anglaises avec des enfants, les résultats ont prouvé que ces trois ensembles de variables ont eu les deux influence directe et indirecte sur le bien-être. Bien que les variables travailler-connexes expliquées pour la plupart de désaccord dans la prévision de la travailler-interférer-avec-famille soient en conflit et de la satisfaction professionelle, les variables de personnalité ont expliqué la plupart de désaccord dans la prévision de familleinterférer-avec-travaillent le conflit. De même, dans la prévision des symptômes de détresse, les variables démographiques ont expliqué la plupart de désaccord. Les réponses qualitatives ont

Correspondence to: Noraini M. Noor, Department of Psychology, International Islamic University, Jalan Gombak, 53100 Kuala Lumpur, Malaysia.

ISSN 1366-8803 (print)/ISSN 1469-3615 (online)/03/030297-23 ㄷ 2003 Taylor \& Francis Ltd DOI: $1080 / 1366880032000143474$ 
fourni par les femmes ont complété ces résultats. Le modèle proposé est vu pour fournir un meilleur ajustement des rapports complexes qui peuvent exister entre les nombreuses variables entourant le travail des femmes et la famille vit par opposition à la précédente qui ont considéré seulement un ensemble de variables.

Mots Clefs: Variables de travail et famille relate; conflit de travaille-famille; bien-être; personnalité; satisfaction de travail; détresse

\section{Introduction}

The last three decades have seen a large increase in the number of women entering the paid labour force. For example, in the United Kingdom, from 1971 to 1990 , the number of married women going out to work has increased from 50 to $71 \%$ (Office of Population Censuses and Surveys, UK, 1991). Further, in 1997, women accounted for just over $49.5 \%$ of the total work force, and according to government projections this percentage is expected to rise until the year 2006 (Employment Service, 1998; UK). Despite this increase in women's employment, however, there appears to be little erosion in the strength of the gender-role expectations concerning men and women's roles in society. While the work role is seen to be men's primary domain, women are still primarily responsible for the home and children (Doucet, 2000; Lundberg et al., 1994; Windebank, 2001). As such, employed women have to juggle the demands from both work and family roles to a greater degree than employed men.

Work-family conflict is experienced when demands from one role domain interfere with participation or performance of the other role (Greenhaus \& Beutell, 1985). For example, when one devotes extra time and energy into the work role (or the family role), the family role (work role) is assumed to suffer. Two types of work-family conflict have been identified; work-interfering-withfamily (WIF) and family-interfering-with-work (FIW) (Frone et al., 1992). WIF conflict occurs when work-related activities spill over or interfere with home responsibilities (e.g. bringing work home and trying to complete them at the expense of family time) and FIW conflict arises when family-role responsibilities spill over or impede work activities (e.g. having to cancel an important meeting because a child is suddenly taken ill). Although strongly correlated with one another, they are conceptually and empirically distinct constructs (Duxbury et al., 1994; Frone et al., 1992). While the best predictors of WIF conflict are work-related variables, the antecedents of FIW conflict are mainly family-related variables (Kinnunen \& Mauno, 1998).

Research has indicated that work-family conflicts are associated with diminished satisfactions and lower levels of psychological well-being (e.g. Frone et al., 1992; Hughes \& Galinsky, 1994; Kinnunen \& Mauno, 1998; Kossek \& Oseki, 1998; Perrewe et al., 1999; Thomas \& Ganster, 1995). Excessive work-family conflict has also been associated with dysfunctional social be- 
haviours such as destructive parenting (Stewart \& Barling, 1996) and alcohol consumption (Frone et al., 1993).

Although both men and women may experience work-family conflict, women report more conflict than men due to them spending more combined time on work and family activities (Frone et al., 1992; Hammer et al., 1997; Lundberg et al., 1994). For example, the study by Lundberg et al. (1994) comparing total workload (sum of paid and unpaid work), conflict between demands of work and family, and control over housework between men and women in white-collar occupations, showed that number of children at home was a crucial factor with regard to these variables. In families with no children at home, the total workload of full-time employed men and women was about 60 hours per week. For women, the number of hours per week increased rapidly with children at home, but this increase was much smaller for men. In families with three or more children, women's total work load was almost 90 hours and men's about 70 hours a week-a mean gender difference of about 2.5 hours a day. In addition, conflict between demands of work and family roles increased and control over home and household work decreased with number of children at home. Consequently, in the present study, the focus is only on women, although it is recognised that men also experience work-family conflict to some extent.

As shown by previous studies, pressures arising from both the work and family roles can lead to conflict between these two domains. These pressures include time spent in work or family activities, stressors within the work or family domains, and high involvement in work or family life (e.g. Adams et al., 1996; Aryee et al., 1999; Beutell \& Wittig-Berman, 1999; Frone et al., 1997). Because of the interdependence of work and family in relation to well-being, this conflict between work and family may also be considered as a source of stress that influence well-being. As suggested by Frone et al. (1992), work-family conflict may reflect the goodness of fit between work and family life and may function as a mediator between conditions at work and family and outcomes. This is so, because a number of studies have shown that work and family conditions alone do not account for much variance in overall well-being (e.g. Amatea \& Fong, 1991; Noor, 1996), suggesting that there may be other processes at work. One that has been hypothesised and tested is this intervening role of work-family conflict (Russell, Frone \& Cooper, 1992). Many studies have in fact viewed work-family conflict as a mediator of relationships between work and family role pressures and individual well-being (e.g. Aryee et al., 1999; Frone et al., 1992, 1997).

The present study was carried out to test an exploratory model that included work- and family-related variables, both types of work-family conflict and well-being. The model also incorporated demographic and personality variables. This is deemed necessary because the links between work, family and well-being are complex and researchers need to specify multiple underlying pathways or processes by which work-family conflict may lead to health impairment. This is so because stress processes are not invariant; both 
personality and environmental factors influence the relationships between stress and outcomes (see Parkes, 1994). For example, Carlson (1999) showed that individual variables (Type A behaviour and negative affectivity) explained significant additional variance beyond those attributed by the role variables.

\section{Literature review and hypotheses}

Frone et al. (1992) formulated and tested two models of the antecedents and outcomes of work-family conflict, and the interrelationship between WIF and FIW conflicts. While one model did not include a direct path between workfamily conflict and depression, the other did. They found that the latter model had a better fit than the former. In this model, work-family conflict was found to act as an intervening pathway between work- and family-related variables and individual well-being, and that the two forms of conflict were reciprocally related to one another. Subsequent studies have followed suit in viewing work-family conflict as a mediator of relationship between work and family role experiences and individual well-being (Aryee et al., 1999; Beutell \& WittigBerman, 1999; Frone et al., 1997; Kinnunen \& Mauno, 1999).

On the basis of these studies the following model was developed (see Figure 1). The model shows that demographic, personality, and work and family-related variables influence well-being, either directly or indirectly via work-family conflict. This model extends previous ones (e.g. the model

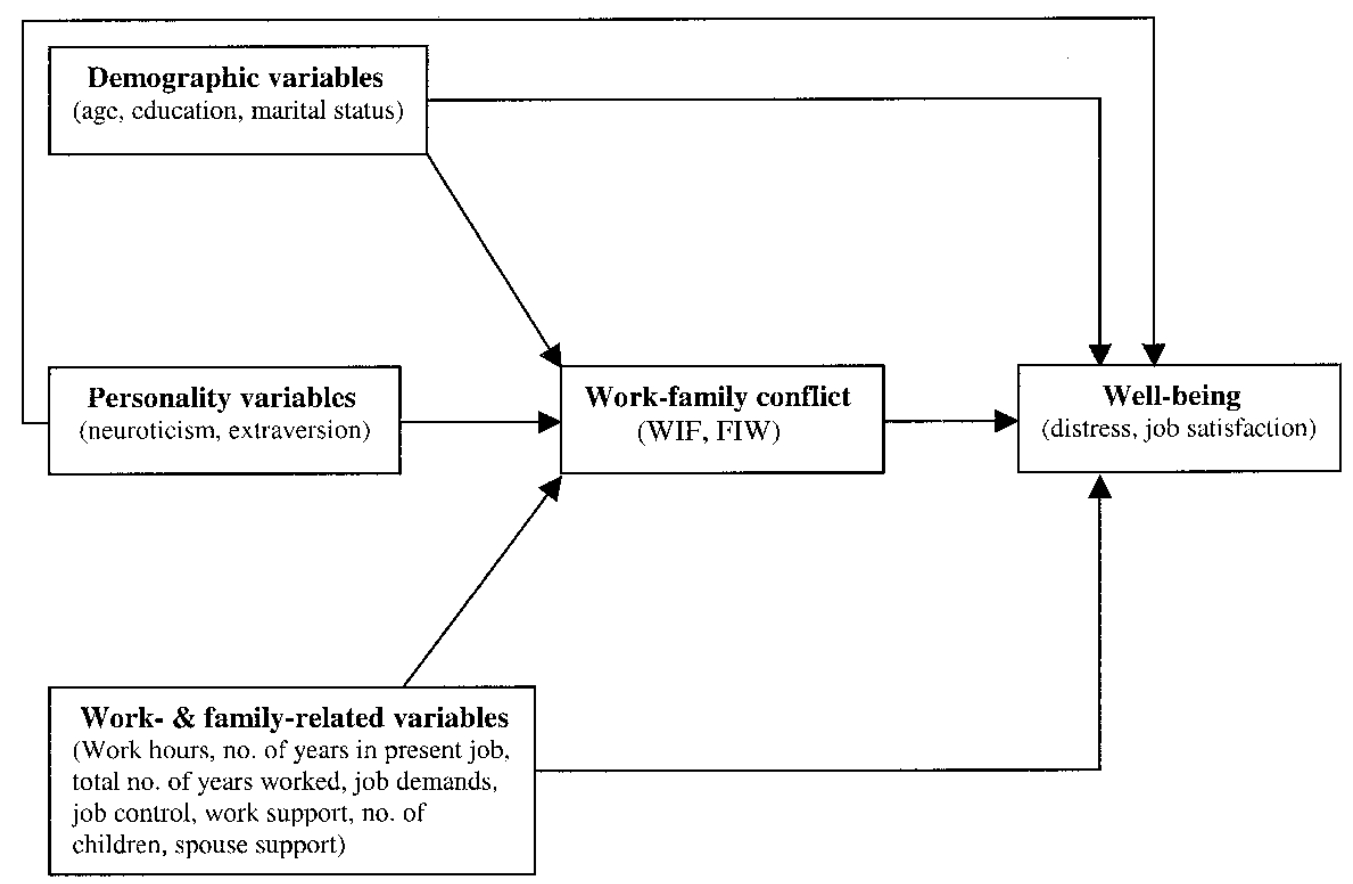

FIGURE 1. The framework of the study. 
proposed by Frone et al., 1992) by incorporating two additional sets of variables, demographic and personality. The inclusion of these different sets of variables in the model (demographic, personality and work- and family-related variables) would give a better representation of the complex relationships between the many variables that may exist in women's work and family lives.

The demographic variables of age, educational level and marital status were chosen because they have been found to be related to well-being (measured by job satisfaction and distress symptoms in the present study). For example, age has been shown to be correlated with job satisfaction (Hassell \& Perrewe, 1993) and psychological symptoms of distress (Noor, 1995). As demonstrated by Ross and Huber (1985), when other aspects of status are held constant, education is the single most important aspect of status for women's well-being. In addition, for women, whether employed or not, education has the largest effect on reducing distress. Both married men and women have been shown to be happier and more satisfied than those who are not married, whether they are divorced, widowed or have never married (Stack \& Eshleman, 1998). Therefore, it is predicted that these demographic variables chosen, age, marital status and educational level will be related directly to well-being. These hypotheses are specified as follows:

H1a: Age will be positively related to job satisfaction and inversely associated with distress symptoms; i.e. older women will report higher job satisfaction and lower distress as compared to younger women. H1b: Education will be positively related to job satisfaction and inversely associated with distress; i.e. women with higher educational levels will report higher job satisfaction and lower distress as compared to those with lower education.

H1c: Marriage will be inversely associated with distress only; i.e. married women will report lower distress as compared to single women (no correlation is hypothesised for marital status and job satisfaction because job satisfaction is domain-specific and has not been shown to relate to marital status)

Personality variables, not usually considered within these relationships, were incorporated as predictors of work-family conflict and well-being. Studies have shown that the personal resources women bring with them into their roles explained more of the variance in reported strain symptoms than the role stressors alone (e.g. Amatea \& Fong, 1991). Two personality traits, neuroticism and extraversion, were chosen in the present study because they have been widely researched (Kline, 1993). Costa and McRae (1980, 1984) have shown that these two personality traits can account for a significant variance in well-being measures. The findings by Noor (1996) examining the correlates of women's well-being showed that these two personality variables accounted for the largest proportion of explained variance in well-being measures compared to demographic and role-related variables. Neuroticism, which is similar to negative affectivity (or NA, a relatively stable personality trait that leads people to 
emphasise the negative side of their experience, Watson and Clark, 1984), has been shown to influence the stressor-strain relationship in several ways: as a confound, a moderator, or simply having direct effects (see Burke et al., 1993; Eysenck, 1991; Moyle, 1995; Noor, 1997). Among these effects, the direct effect of NA on strain symptoms is the strongest (Moyle, 1995). Extraversion (a personality trait that predisposes people to experience positive emotional states and feel good about themselves and about the world around them), on the other hand, has been shown to be related to positive mental health (Furnham \& Brewin, 1990; Lu, 1994). On the basis of these findings, the following hypotheses are proposed:

H2a: Those with high neuroticism scores will report high levels of conflict and reduced well-being (high distress and low satisfaction). $\mathrm{H} 2 \mathrm{~b}$ : Those with high extraversion scores will report low levels of conflict and increased well-being (low distress and high satisfaction). $\mathrm{H} 2 \mathrm{c}$ : The effects of neuroticism on well-being will be mediated by perceptions of work-family conflict, such that those with high neuroticism scores will report more conflict which will lead to reduced well-being (high distress and low satisfaction).

$\mathrm{H} 2 \mathrm{~d}$ : The effects of extraversion on well-being will be mediated by perceptions of work-family conflict, such that those with high extraversion scores will report less conflict which will lead to increased well-being (low distress and high satisfaction).

The work-related variables included were number of work hours, number of years in the present employment, total number of years worked, job demand, job control and workplace support. While number of work hours, number of years in present employment, and total number of years worked were objective and straightforward measures, the latter three measures consisted of separate scales. Whereas job demand (which refers to workload, time pressures, and conflicting demands) and job control (which refers to the extent that workers can exert control over tasks and the working environment, and opportunities for learning and developing new skills) were measured by a standardised scale (Karasek, 1979), workplace support (which refers to workers' access to emotional, informational and other kinds of assistance at the workplace) was assessed by a scale developed specifically for the study. In line with the findings of previous studies, these work-related variables were expected to be related to work-family conflict and well-being (e.g. Kinnunen \& Mauno, 1998). Number of years in present employment and total number of years worked are predicted to be positively associated only with job satisfaction as they are specific to the job domain. Furthermore, if women were distressed with their present jobs, they would either have taken other jobs or stopped working altogether. Thus, the following hypothesis is proposed:

H3a: Number of years in present employment and total number of years worked will be positively related to job satisfaction. 
It is also predicted that the association between work hours and conflict/ well being will be high. Because working long hours create difficulty for women with families, it can act as a measure of a job stressor and as an indication of one's involvement or commitment to the job. A review by Barnett (1998) on the main effect of work hours on distress implied that this pathway between work and distress might be mediated by other factors. At the same time, long work hours can also influence well-being directly (Negrey, 1993). These arguments suggest the following hypotheses:

H3b: Those working long hours will report higher distress and lower satisfaction than those with lesser work hours.

H3c: The effect of long work hours on well-being will be mediated by work-family conflict, such that those who work long hours will experience higher WIF conflict which will lead to reduced well-being (high distress and low satisfaction).

Job demand is usually positively associated with strain, particularly in the prediction of anxiety (Broadbent, 1985) and to more general psychological distress (Karasek, 1979; Karasek \& Theorell, 1990). Job demand has also been shown to affect well-being via work-family conflict (Aryee et al., 1999; Frone et al., 1992). Therefore, it follows that

H4a: Those with high job demand will report higher distress and lower job satisfaction compared to those with low demand.

H4b: The effects of job demand on well-being will be mediated by work-family conflict, such that those with high demand will experience higher conflict which will lead to reduced well-being (high distress and low satisfaction).

Job control, referring to the amount of discretion available to an individual in his/her work environment has been widely investigated and generally found to be negatively associated with strain; low control predicting high strain (Parkes, 1989). Thus,

H5a: Those with high job control will report lower distress and higher job satisfaction compared to those with low control.

In terms of workplace support, whereas Blau (1981) found supervisory and co-worker support to have direct effects on job satisfaction, Thomas and Ganster (1995) showed that family supportive work variables (such as flexible work schedules and supportive supervisors) had direct effects on reducing work-family conflict. As such the following hypotheses are proposed:

H6a: Those with high workplace support will report lower distress and higher job satisfaction compared to those with low support.

H6b: Those with high workplace support will report low conflict levels.

Number of children and spouse support were used to measure familyrelated variables. Number of children at home is related to increase distress via 
increase family demands and more work-family conflict (Lundberg et al., 1994; Perrewe et al., 1999). Therefore:

H7a: Number of children will be positively related to FIW conflict, such that those with more children will report more FIW conflict.

However, because the sample was made up of educated women with more resources (both personal and material), number of children will not necessarily reduce their well-being (high distress and low satisfaction). Thus, no prediction was made regarding the relationship between number of children and wellbeing.

In terms of spouse support (which refers to emotional, companionship, and instrumental support women received from their spouses), Adams et al. (1996) found that higher levels of family emotional and instrumental social support were associated with lower levels of family and work interference. Spouse support has also been shown to result in less marital stress (Roskies \& Lazarus, 1980) and low work-family conflict (Holahan \& Gilbert, 1979). Thus, the following hypotheses are proposed:

H8a: Those with high spouse support will report low conflict levels.

H8b: Those with high spouse support will report enhanced well-being (low distress and high satisfaction).

\section{Method}

\section{Subjects}

Subjects were 147 employed women, solicited from 'Parents at Oxford' and the Oxford City Council. 'Parents at Oxford' is a support group for parents with school-aged children in the Oxford area in the UK. It has about 400 parents on its mailing list, with many of them being members of the University. A short description of the study was e-mailed to these parents and 152 indicated their interest in the study (a response rate of 38.0\%). Questionnaires were sent to these women and 127 completed questionnaires were received (a response rate of $83.6 \%$ of those willing to participate). In addition, 50 questionnaires were sent to the Oxford City Council after permission had been sought. Twenty completed questionnaires were received making the total sample to 147 .

While $56.5 \%$ of the women were employed part time (working less than 36.5 hours a week), the rest were in full-time employment (working more than 36.5 hours a week). The sample had an average work hour of 32.3 a week (standard deviation, 9.2 hours). The age range of the sample was 24-55 years with an average age of 39.19 years (standard deviation, 6.1 years). The sample was well above average in terms of education, with $72.1 \%$ of the women having a college or university degree. However, only $36.7 \%$ were employed in professional occupations.

The majority were married $(83.0 \%)$ and the rest were separated, divorced or widowed $(14.3 \%)$ or single $(2.7 \%)$. All, however, had children living at 
home. The number of children ranged from one to four, with the majority having either one child $(38.8 \%)$ or two children $(52.4 \%)$.

\section{Measures}

Demographic information. The following demographic information was collected from each woman: age (in years), education (coded hierarchically corresponding to: primary education, 1 ; ' $\mathrm{O}$ ' levels or equivalent, 2; 'A' levels or equivalent, 3; some college (without degree), 4; college/university degree, 5; and graduate or professional education beyond college/university degree, 6), marital status (coded hierarchically corresponding to: single, 1; married/cohabiting, 2; separated/divorced, 3; and widowed, 4) and number and ages of children at home.

Personality variables. Neuroticism and extraversion were assessed by means of the 24 forced-choiced items of Eysenck's EPQ-R Short Scale (Eysenck et al., 1985). Sample items for neuroticism are 'Does your mood often go up and down?' and 'Do you ever feel "just miserable" for no reason?' For extraversion, examples are 'Are you a talkative person?' and 'Are you rather lively?' Coefficient $\alpha$ values were 0.81 for neuroticism and 0.88 for extraversion.

Work-related variables. These included number of work hours (per week), number of years in present employment, total number of years worked, job demand, job control and workplace support. While the first three were objective measures, separate scales assessed the latter three.

Job demand and control (or 'discretion' as used by Karasek) were measured by means of the 15-item scale derived from Karasek (1979). Demand items focus on time pressure and workload, while control/discretion items are concerned with opportunities for control, autonomy and decision-making in the work setting. While sample items for job demand include 'Have to work very hard' and 'Lots of work', examples of control items are 'Allows you to make your own decisions' and 'Allows freedom'. Participants respond to each item on a four-point scale (1-4) from 'not at all' to 'very much indeed'. The $\alpha$ coefficient for the present sample was 0.83 for work demand and 0.88 for work control.

A four-item scale was developed specifically for the study to measure workplace support. Sample items are 'Enjoys company of people at work' and 'Fob security'. Similar to previous work scales, participants respond to each item on a four-point response range (1-4) from 'not at all' to 'very much indeed'. Coefficient $\alpha$ for the scale was 0.63 .

Family-related variables. Family-related variables were measured by number of children at home and spouse support. Spouse support was measured by eight 
items from a factor analysis of the modified scale of Baruch and Barnett's (1986) spousal experience. Sample items include 'Good communication' and 'Husband backing you up'. Using a four-point scale (1-4), participants were asked to indicate the extent to which each item was applicable to them. The coefficient $\alpha$ value for this eight-item scale with the present sample was 0.90 .

Work-family conflict. Work-family conflict was assessed by the 22-item workfamily conflict scale developed by Kelloway et al. (1999). The scale distinguishes between WIF and FIW conflicts and between strain- and time-based conflicts (while time-based conflict is experienced when time pressures associated with one role prevent one from fulfilling the expectations of the other role, strainbased conflict is experienced when strain or fatigue in one role affects performance in the other). The items used a four-point Likert response scale ( $1=$ 'never', $4=$ 'almost always'), with higher scores indicating higher conflict. The scale provides a four-fold classification of work-family conflict (i.e. timebased WIF, strain-based WIF, time-based FIW, and strain-based FIW), which has not been properly considered previously. However, as there were differences in the present sample compared to that reported by Kelloway et al. (1999), a factor-analysis was carried out to check for differences in the underlying factor structure. The present analysis was only able to identify between WIF and FIW conflicts, not between the strain-based and time-based conflicts. Therefore, the present study only made a distinction between WIF and FIW conflicts. Sample items for the WIF conflict scale are 'Fob demands keep me from spending the amount of time I would like with my family' and 'I do not listen to what people at home are saying because I am thinking about work'. For FIW conflict scale, sample items include 'When I am a work, I am distracted by family demands' and 'Things going on in my family life make it hard for me to concentrate at work'. The $\alpha$ coefficients for the WIF and FIW scales (each with 11 items) were 0.84 and 0.81 , respectively.

Well-being. Well-being was measured by job satisfaction and symptoms of psychological distress. While the five-item job satisfaction scale of Hackman and Oldham (1975) was used to measure job satisfaction, distress was assessed by the 12-item General Health Questionnaire (GHQ-12; Goldberg, 1978). The job satisfaction scale measures the degree to which respondents are satisfied and happy with the job, whereas the GHQ-12 assesses the extent to which respondents experienced a list of somatic and affective symptoms over the past 6 weeks. Sample items for the job satisfaction scale are 'Generally speaking, I am satisfied with this job' and 'I frequently think of quitting this job'. For the distress scale, sample items include 'In the past six weeks have you been able to concentrate on whatever you're doing?' and 'In the past six weeks have you lost much sleep over worry?' Both measures used the Likert scale scoring [a seven-point scale from 'disagree strongly' (1) to 'agree strongly' (7) for job satisfaction, and a four-point 
scale for distress symptoms with higher scores indicating higher levels of distress].

Both measures have been validated and have been shown to have good psychometric properties (Banks, 1983; Banks et al., 1980). Cronbach $\alpha$ values for the present sample were 0.79 for job satisfaction and 0.84 for distress symptoms.

In addition to these quantitative measures, qualitative data in the form of women's own perception of their role experiences were collected. This was deemed necessary because it would complement the quantitative analysis by emphasising more on the meaning/significance of a particular experience from the individual woman's point of view.

Women were asked to write down their experiences (both positive and negative) in each of their roles of worker, spouse and mother. They were also asked about the kinds of support available within their roles, how they handle their roles, how satisfied they were with their life in general, and any other comments about their work, family and health that they may think useful. All 147 women wrote something on their work, family and health. The women's answers were then analysed for certain trends or patterns across cases.

\section{Data analysis}

First, zero-order correlations were computed to assess the general pattern of relationships among the variables. Second, a path analysis was used to examine the hypothesised relationships depicted in Figure 1 using a series of hierarchical multiple regression. Work-family conflict was regressed on the demographic variables in the first step, followed by personality and role variables on the second and third steps. Subsequently, well-being was regressed on demographic, personality and role variables; and on the final step, work-family conflict was entered.

\section{Results and discussion}

\section{Quantitative analyses}

The means, standard deviations and intercorrelations among the study variables are presented in Table 1. In general, the correlations ranged from low to moderate and were in the expected direction.

The results of the hierarchical regression analyses predicting work-family conflict and well-being are shown in Tables 2 and 3. These results are also presented as path models in Figure 2 . In the figure, standardised $\beta$ weights are used to estimate the path coefficients and only those, which reached the 0.05 level of significance, are shown.

Although it was predicted that demographic variables would be directly related to well-being, the results showed that this holds only for marital status in relation to distress. Similar to previous findings, married women reported 


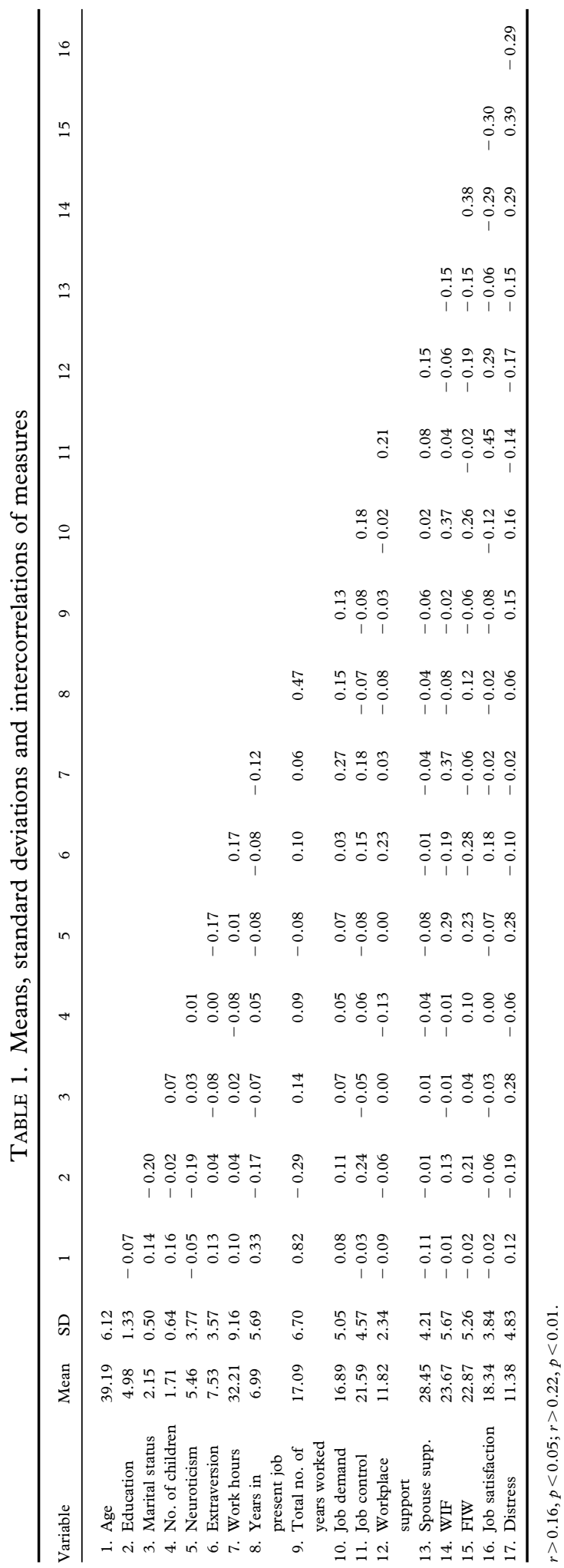


TABLE 2. Path analysis results predicting work-family conflict

\begin{tabular}{|c|c|c|c|c|c|c|}
\hline \multirow[b]{2}{*}{ Variable } & \multicolumn{3}{|c|}{ WIF } & \multicolumn{3}{|c|}{ FIW } \\
\hline & $\beta$ & $R^{2}$ & $\Delta R^{2}$ & $\beta$ & $R^{2}$ & $\Delta R^{2}$ \\
\hline Demographic & & 0.024 & 0.024 & & 0.058 & 0.058 \\
\hline Age & 0.01 & & & -0.02 & & \\
\hline Education & 0.16 & & & $0.24^{\star}$ & & \\
\hline Marital status & 0.03 & & & 0.10 & & \\
\hline Personality & & 0.158 & 0.134 & & 0.190 & 0.132 \\
\hline Neuroticism & $0.32^{\star \star}$ & & & $0.24^{\star}$ & & \\
\hline Extraversion & -0.15 & & & $-0.24^{\star}$ & & \\
\hline Work-related variables & & 0.362 & 0.204 & & 0.282 & 0.092 \\
\hline No. of work hours & $0.31^{\star \star}$ & & & -0.07 & & \\
\hline Years in present job & -0.10 & & & 0.15 & & \\
\hline Total no. of years worked & 0.13 & & & 0.01 & & \\
\hline Job demand & $0.26^{\star \star}$ & & & $0.23^{\star}$ & & \\
\hline Job control & -0.01 & & & -0.03 & & \\
\hline Workplace support & -0.02 & & & -0.12 & & \\
\hline Family-related variables & & 0.375 & 0.013 & & 0.304 & 0.022 \\
\hline No. of children & 0.01 & & & 0.09 & & \\
\hline Spouse support & -0.12 & & & -0.12 & & \\
\hline
\end{tabular}

$F(13,133)=5.91, p<0.0001 ; F(13,133)=4.30, p<0.0001 ;{ }^{\star} p<0.01,{ }^{\star \star} p<0.001$.

lower distress levels than the single, divorced or widowed (see Table 3). In addition, while it was not hypothesised, the results also showed that the effects of education on well-being is mediated by work-family conflict, where those with higher levels of education reported more conflict which then leads to lower well-being (see Figure 2). This finding is not totally unexpected because women with higher education levels would tend to hold more senior positions with more responsibilities, which may lead to higher levels of conflict (both kinds of conflict will be experienced due to their reciprocal relationship with one another) to impact negatively on well-being. Age, however, was not related to well-being

Table 2 shows that the predictors of WIF conflict and FIW conflict are different. While work-related variables explained for the most variance in WIF conflict $\left(\Delta R^{2}=0.204\right)$, personality variables accounted for the most variance in FIW conflict $\left(\Delta R^{2}=0.132\right)$. The former finding is consistent with previous studies (e.g. Mauno \& Kinnunen, 1998). The latter finding, however, is more interesting and implies that the personal makeup of these women is important in them experiencing FIW conflict. Those with high neuroticism scores and low extraversion scores appear to be less able to prevent family matters intruding into the workplace. Although past studies have shown family-related variables to be associated with FIW conflict, the present study suggests that personality variables are more important with this, rather highly educated sample. 
TABLE 3. Path analysis results predicting well-being

\begin{tabular}{|c|c|c|c|c|c|c|}
\hline \multirow[b]{2}{*}{ Variable } & \multicolumn{3}{|c|}{ Job satisfaction } & \multicolumn{3}{|c|}{ Distress } \\
\hline & $\beta$ & $R^{2}$ & $\Delta R^{2}$ & $\beta$ & $R^{2}$ & $\Delta R^{2}$ \\
\hline Demographic & & 0.005 & 0.005 & & 0.102 & 0.102 \\
\hline Age & -0.00 & & & 0.06 & & \\
\hline Education & -0.07 & & & -0.13 & & \\
\hline Marital status & -0.05 & & & $0.25^{\star}$ & & \\
\hline Personality & & 0.047 & 0.042 & & 0.168 & 0.066 \\
\hline Neuroticism & -0.04 & & & $0.25^{\star}$ & & \\
\hline Extraversion & $0.19^{+}$ & & & -0.04 & & \\
\hline Work-related variables & & 0.321 & 0.274 & & 0.227 & 0.059 \\
\hline No. of work hours & -0.07 & & & -0.05 & & \\
\hline Years in present job & 0.07 & & & -0.00 & & \\
\hline Total no. of years worked & $-0.31^{+}$ & & & 0.16 & & \\
\hline Job demand & $-0.16^{+}$ & & & 0.15 & & \\
\hline Job control & $0.47^{\star \star}$ & & & -0.08 & & \\
\hline Workplace support & $0.17^{+}$ & & & -0.15 & & \\
\hline Family-related variables & & 0.335 & 0.014 & & 0.256 & 0.029 \\
\hline No. of children & -0.03 & & & -0.12 & & \\
\hline Spouse support & -0.12 & & & -0.14 & & \\
\hline Work-family conflict & & 0.414 & 0.079 & & 0.371 & 0.081 \\
\hline WIF & $-0.24^{\star}$ & & & $0.19^{+}$ & & \\
\hline FIW & $-0.19^{+}$ & & & $0.32^{\star \star}$ & & \\
\hline
\end{tabular}

Figure 2 also shows that the two personality variables influence well-being directly and indirectly. However, the effects of neuroticism and extraversion on well-being were different. Whereas neuroticism had a direct positive effect on distress, it also influenced well-being indirectly via work-family conflict. Extraversion, on the other hand, showed a direct effect on job satisfaction and also affected well-being indirectly through perceptions of work-family conflict. Thus, to a large extent, these findings supported the hypotheses made regarding the effects of these personality variables on conflict and well-being. Whereas the personality variables accounted for a large proportion of the explained variance in the conflict measures, its contribution to well-being was much smaller. These findings support the inclusion of personality variables in the model. First, the results suggest that neuroticism and extraversion are implicated differentially in the complex pathways by which work- and family-related variables influence outcomes. Second, the inclusion of personality variables in addition to work and family-related variables in the predictive model allows for some evaluation of the relative effects of these variables on well-being (and consequently the relative benefits of person-focused and environment-focused interventions to reduce 


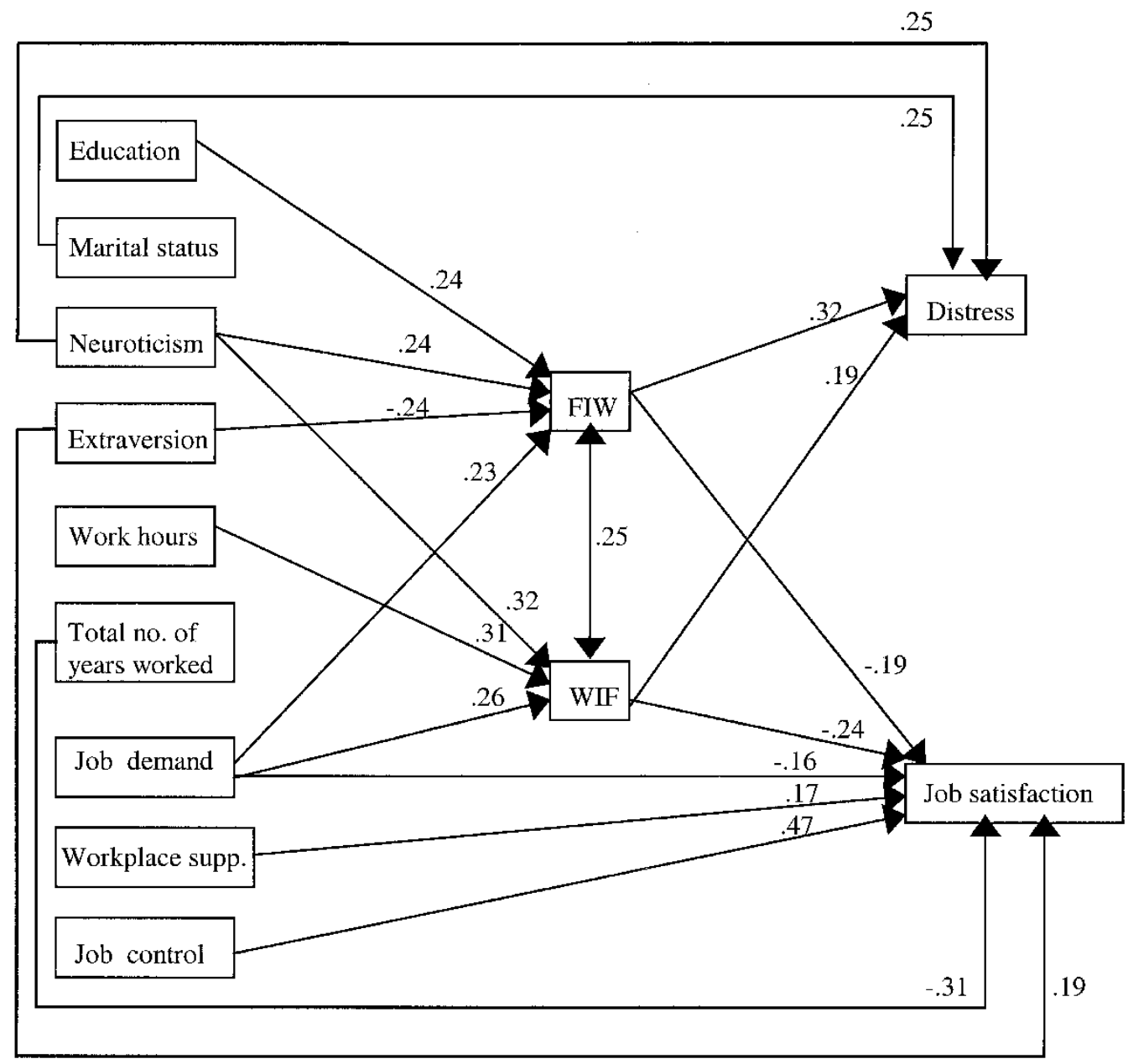

FIGURE 2. The relationship between demographic, personality, role variables, work-family conflict and well-being (only significant path coefficients are shown, $p<.05$ ).

adverse health outcomes). Thus personality variables should be considered in studies examining the relationship between multiple roles and well-being.

Figure 2 also shows that WIF and FIW conflicts are reciprocally related to one another $(r=0.25)$. Again, this observation is consistent with past research (e.g. Kinnunen \& Mauno, 1998).

In terms of work-related variables, total number of years worked was negatively associated with job satisfaction. This negative relationship may be due to fact that many of these women are working part time (working for less than 36.5 hours a week) to balance their family demands. As part-time employees, however, they are not entitled to many of the available work opportunities and benefits and hence, their reported job dissatisfaction. This explanation is also supported by the women's qualitative responses. Contrary to the hypoth- 
esis made, number of years in the present employment was not related to job satisfaction. One possibility can be that women have not been in that particular job long enough to make an assessment. Or the fact that many of these women are working part time and thus are less likely to be concerned with job satisfaction.

Although work hours and job demands were predicted to have both direct and indirect effects on well-being, the results only showed indirect effects of these two work variables on well-being via both forms of work-family conflict to impact upon distress and job satisfaction (see Figure 2 and hypotheses H3b, $\mathrm{H} 3 \mathrm{c}, \mathrm{H} 4 \mathrm{a}, \mathrm{H} 4 \mathrm{~b}$ ). Consistent with past studies, job control showed a strong positive effect on job satisfaction; having control or autonomy at work is extremely important for one's job satisfaction. However, job control was not related to distress.

Surprisingly, the family-related variables used in the study were not related to FIW conflict (or to well-being). It was expected that with increased family demands (more children and lack of spouse support), there would be less time for work, leading to more FIW conflict being experienced and higher distress. The findings, however, only showed work-related variables to be related to work-family conflict. One reason may be that women may perceive the work role as being more 'quantifiable' (they spend a large portion of their time at work, they are paid for they work they do, etc.) than the family role, which is less defined. Another reason may be that once personality and work-related variables are accounted for, family-related variables are no longer significant. Or, women may have given more precedent to the work role considering its economic importance to the well-being of the family. It may also be that the family-related measures used in the study are too limited and that there are other measures not considered such as total family income or the availability and quality of childcare that may be better predictors of FIW conflict.

Regarding the role of support, after taking into account the demographic and personality variables, only workplace support was related to job satisfaction. Spouse support and workplace support were not found to be related to conflict, in contrast to earlier studies. This is important for as shown by Henderson et al. (1981), after controlling for personality and background variables, social support accounted for little variance in the outcome measures. Neuroticism, however, accounted for $69 \%$ of the variance in psychological distress. In short, these researchers showed that most of the cross-sectional relationship between perceived support and mental health was due to their common relationship to neuroticism. Therefore, previous associations of support with conflict may be due to confounding with these demographic or personality variables (Aryee et al., 1999). Once these variables are controlled, as in the present study by using a hierarchical regression analysis where demographic and personality variables were entered into the analysis prior to the support measures, only workplace support was positively related to job satisfaction.

Consistent with a growing body of literature, work-family conflict had significant relationships with work and individual well-being (e.g. Frone et al., 
1996; Kelloway et al., 1999). Both forms of conflict were negatively related to job satisfaction and positively related to distress symptoms (see Figure 2).

\section{Qualitative responses}

The qualitative responses provided by the women provided another perspective to these findings. In general, women were satisfied with life as reflected in the following examples 'Reasonably satisfied - balance between very satisfied with some aspects and not satisfied with others' (librarian, 41 years), and 'I am satisfied with life at present. Balance of work and home is about right. I get a lot of pleasure from working but also look forward to getting home' (editorial manager, 37 years), although a few felt otherwise \{examples ' $I$ am very dissatisfied and feel totally constrained by my need to work and be around for my 9-year-old. My work is very boring and I tried hard to change it. My age is against any retraining' (secretary, 49 years) and 'Not very. Have a wonderful daughter but not enough time to spend with her because of the financial necessity of working full time. Fob is demanding but boring most of the time. Tiredness from continued broken nights. Too little time to do the things I enjoy doing outside work' (editor, 38 years)\}. As shown in these examples, women who were satisfied feel that they had some sort of balance between their work and family. Those who reported feeling dissatisfied somehow had not achieved this balance or had some problems pertaining to a role or between roles. Of course those who enjoyed their work also reported certain problems, but overall, the positive factors (such as job satisfaction, financial independence, social contacts, etc.) outweighed the negative ones (such as problems in commuting to work, work that was not challenging, lack of responsibility, under constant pressure at work, no prospect for promotion, etc).

However, combining work and family was demanding, as reported by these women,

I have problems doing the juggling of work and kids and my marriage comes third. I basically have no energy and put no effort into it, and am happier when spouse is away from home. Not planning divorce, just unable to cope with the demands currently. (lecturer, 40 years)

Work alone is fine, but trying to combine it with family, with the constraints of wanting to be there for the children is a source of frustration, which varies from intense to mild. Dogged by the guilt and desire to be a mother and maddened by the fact my time is so circumscribe, and I can't give or be involved professionally as far as I'd like to be. As much as I wish you could, practically speaking I do not believe you can have it all. (librarian, 42 years)

And

Although my work is very important to me and I would not wish to be without it, my family is more important to me and, indeed, the number 
one reason why I work is to provide economic support. Nevertheless, I would like to have more time to devote to my work and sometimes resent that the number one responsibility for child care (school runs, etc.) always fall on me rather than my husband! (statistician, 37 years)

Because childcare and the home are still perceived to be women's responsibility, they had to work at home and at the workplace.

One option chosen by several women was to reduce the number of working hours, which allowed them the flexibility of being there for the family while still being employed. This trade-off also had other benefits as reflected by the following respondent

I was on maternity leave for a year in 1998-1999 and arranged to work half time for 5 years on my return. I've been doing it for a term and it's brilliant - a colleague commented on how less stressed I look. Things are financially tight but I resent the amount of housework I end up doing, but it's wonderful to feel that I'm meeting all the demands of the job and am really there for my children (I work from 9 to 2). (lecturer, 34 years)

However, doing so had its costs, in terms of lost job opportunities, promotion, and lesser pay.

On the other hand, those who continued working full time even after having their children reported being stretched to their limits. Supportive spouses, work colleagues and supervisors helped extremely as shown by these examples

I am 'lucky' to have a job which I can do in school hours, a comfortable home close to work and school and a supportive husband. My husband does the shopping and cooking and even cleans the house. (editor, 43 years)

Overworked and underpaid, under constant stress to publish, raise research monies, but blessed with a supportive department, good job and wonderful family. (lecturer, 41 years)

And

January 99-June 99 - looking after sick mother in her home until she died. Very stressful juggling her/child/job/house/husband/outside commitments. Shared care with older sister but she is not coping with bereavement. Ongoing worry, as we are close, and feel that health is affected due to stress of the past year. Demanding husband and child - feel there is little time or energy left for myself. Moral and practical support from friends has been extremely invaluable. (research assistant, 45 years)

Women reported having problems at work but having a supportive home environment seem to buffer them from the adverse effects of work (and vice 
versa). In the quantitative analysis, however, only workplace support was related to job satisfaction. Non-work sources of support, as mentioned in these examples, were not related to increase well-being.

As can be seen in these responses, a number of women reported difficulty with combining work and family, especially in terms of child care, some feeling of 'guilt' for not being there for the children, not enough time for family, etc., as reported in much other research (e.g. Lewis et al., 2000). Women also reported that having been in this balancing situation for quite sometime, they had developed certain ways of coping, which greatly reduced the demands that they faced. Example:

I've managed to arrange my work load and deadlines around the children's day. However, I have to be very disciplined to do so. (designer, 45 years).

Many women enjoyed having their family and acknowledged that combining work with family would entail some difficulties and sacrifices. Examples:

Combining family life, paid work and voluntary work will, for me, always involve compromise and stress. Sometimes I feel I have the 'best of all world'; other times I feel I'm not able to give of my best in any one sphere because of competing demands from the others ... My work is enjoyable, fulfilling and demanding, as is my family. (medical practitioner, 41 years)

And

I am not able to build a reasonable career because I am trying to fit work into family life, something I may (or may not) regret later (local government officer, 35 years)

Therefore, combining work and family may be stressful, but there are also rewards and gratifications derived from those roles. Many women also reported the lack of time for oneself.

The balance between positive and negative effects of occupying both roles seemed to vary over time, and between women depending on their age, marital status, family size, types of occupation and personality. Example:

At different stages of my working life I would have answered many of the questions differently - e.g. when my children were small it was much more difficult to 'do it all' and work was less enjoyable. Now there is no conflict there, but since my marriage broke down recently some quite 'other' strains have come into view and I consider my work as one constant in life. Perhaps in another few years I would answer the questions differently again. (secretary, 46 years).

These findings from both quantitative and qualitative data suggest that the model used, incorporating three main sets of variables (demographic, personal- 
ity, as well as work- and family-related variables) in the prediction of well-being (distress and job satisfaction), was indeed useful. The model also provided a test of the indirect effect of these variables on well-being, via work-family conflict. The findings of the study showed that these three sets of variables could have both direct and indirect influence on well-being. Although work-related variables explained the most variance in the prediction of WIF conflict, in terms of FIW conflict, personality variables were the most important. Similarly, in the prediction of distress symptoms, demographic variables accounted for the most variance. Thus, the incorporation of these different sets of variables provided a better picture of the complex relationship that exists between the many variables encompassing women's work and family lives.

Two practical implications can be drawn from these findings. Because work-related variables accounted for the most variance in the prediction of WIF conflict and job satisfaction, workplaces need to play a more proactive role to help women integrate their work and family lives. Managers in workplaces need to recognise that issues pertaining to work and family involve work as much as family, and that many of the root causes of work-family conflict stem from the way organisation and work are structured (Rapoport et al., 2002).

At the same time, greater gender equity in the family is needed and this would entail some delegation, negotiation and redefining of family roles.

These findings, however, should be considered within certain constraints. First, the design of the study was cross-sectional and causal relationships cannot be ascertained. It was assumed that personality and work- and family-related variables preceded well-being, rather than the reverse based on previous findings (e.g. Frone et al., 1992). In addition, the sample was made up of women who were well educated and presumably were in more privileged occupations than the average employed woman. Thus, they may be more in control of their situation and be more resilient as opposed to other employed women. The sample was also made up of women who volunteered to participate, making them somewhat different in some aspects from those who did not respond. However, bearing these limitations, the findings of the study indicated that: (i) work variables may not necessarily be the most important set of variables in relation to well-being; (ii) both forms of conflict predicted well-being; (iii) personality variables should be incorporated in future studies examining roles and well-being; and (iv) positive and negative effects were reported by women occupying work and family roles simultaneously.

\section{Acknowledgements}

This study was carried out in Oxford while the author was on sabbatical leave. The author would like to thank Dr. Kathy Parkes, the Department of Experimental Psychology, University of Oxford, the Commonwealth Fellowship Commission and the International Islamic University Malaysia for making her stay in the UK possible. 


\section{REFERENCES}

ADAms, G.A., KING, L.A. \& KING, D.W. (1996). Relationships of job and family involvement, family social support, and work-family conflict with job and life satisfaction. Fournal of Applied Psychology, 81, 411-420.

AmateA, E.S. \& FonG, M.L. (1991). The impact of role stressors and personal resources on the stress experience of professional women. Psychology of Women Quarterly, 15, 419-430.

ARYEE, S., LUK, V., LEUNG, A. \& Lo, S. (1999). Role stressors, interrole conflict, and well-being: the moderating influence of spousal support and coping behaviors among employed parents in Hong Kong. Fournal of Vocational Behavior, 54, 259-278.

BANKs, M.H. (1983) Validation of the General Health Questionnaire in a young community sample. Psychological Medicine, 13, 349-353.

BANKs, M.H., ClegG, C.W., JaCKson, P.R., KeMP, N.J., STAFFoRD, E.M. \& Walls, T.D. (1980). The use of the General Health Questionnaire as an indicator of mental health in occupational studies. Fournal of Occupational Psychology, 53, 187-194.

BARNETT, R.C. (1998). Towards a review and reconceptualisation of the work/family literature. Genetic, Social and General Psychology Monographs, 124, 125-182.

BARUCH, G.K. \& BARNETT, R.C. (1986). Role quality, multiple roles involvement and the psychological well-being in mid-life women. Fournal of Personality and Social Behavior, 3, $578-585$.

Beutell, N.J. \& Wittig-Berman, U. (1999). Predictors of work-family conflict and satisfaction with family, job, career, and life. Psychological Reports, 85, 893-903.

BlaU, G. (1981). An empirical investigation of job stress, service length and strain. Organizational Behavior and Human Performance, 27, 279-302.

Broadbent, D.E. (1985). The clinical impact of job design. British fournal of Clinical Psychology, $24,33-44$.

Burke, M.J., Brief, A.P. \& GEORGE, J.M. (1993). The role of negative affectivity in understanding relations between stressors and strains: A comment on the applied psychology literature. Fournal of Applied Psychology, 78, 402-412.

CARLSON, D.S. (1999). Personality and role variables as predictors of three forms of work-family conflict. Fournal of Vocational Behavior, 55, 236-253.

Costa, P.T. \& MCRAE, R.R. (1980). Influence of extraversion and neuroticism on subjective well-being: Happy and unhappy people. Fournal of Personality and Social Psychology, 38, 668-678.

Costa, P.T. \& McRae, R.R. (1984). Personality as a lifelong determinant of well-being. In C. Matatesta \& C. IzARD (Eds.), Affective processes in adult development and aging (pp. 141156). Beverly Hills: Sage.

Doucet, A. (2000) There's a huge gulf between me as a male carer and woman. Gender, domestic responsibility and the community as an institutional arena. Community, Work and Family, 3(2), 163-184

Duxbury, L., Higgins, C. \& LeE, C. (1994). Work-family conflict: a comparison by gender, family type, and perceived control. Fournal of Family Issues, 15, 449-466.

Eysenck, H.J. (1991). Type A behaviour and coronary heart disease: the third stage. In M.J. Strube (Ed.), Type A Behaviour. Newbury Park: Sage.

Eysenck, S.B.J., Eysenck H.J. \& Barrett, P. (1985). A revised version of the Psychoticism Scale. Personality and Individual Differences, 6, 21-29.

Frone, M.R., Russell, M. \& CoOper, M.L. (1992). Antecedents and outcomes of work-family conflict: testing a model of the work-family interface. Fournal of Applied Psychology, 77, 65-78.

Frone, M.R., RUSSELl, M. \& COOPER, M.L. (1993). Relationship of work-family conflict, gender, and alcohol expectancies to alcohol use/abuse. Fournal of Organizational Behavior, 14, 545558.

Frone, M.R., YARDley, J.K. \& MARKel, K.S. (1997). Developing and testing an integrative model of the work-family interface. Fournal of Vocational Behavior, 50, 145-167. 
Furnham, A. \& Brewin, G.R. (1990). Personality and happiness. Personality and Individual Differences, 11, 1093-1099.

Goldberg, D.P. (1978). Manual of the General Health Questionnaire. Windsor: NFER Publishing.

Greenhaus, J.H. \& Beutell, N.J. (1985). Sources of conflict between work and family roles. Academy of Management Review, 10, 76-88.

Hackman, J.R. \& Oldham, G.R. (1975). Development of the Job Diagnostic Survey. Fournal of Applied Psychology, 60, 159-170.

Hammer, L. B., Allen, E. \& Grigsby, T. D. (1997). Work-family conflict in dual-earner couples: within-individual and crossover crossover effects of work and family. Fournal of Vocational Behavior, 50, 185-203.

Hassell, B. \& Perrewe, P. (1993). An examination of the relationship between older workers' perceptions of age discrimination and employee psychological states. Fournal of Managerial Issues, $V, 109-120$.

Henderson, S., Byrne, D.G. \& Duncan-Jones, P. (1981). Neurosis and the social environment. New York: Academic Press.

Holahan, C.K. \& Gilbert, L.A. (1979). Conflict between major life roles: Women and men in dual career couples. Human Relations, 326, 451-467.

Hughes, D.L. \& Galinsky, E. (1994). Gender, job and family conditions, and psychological symptoms. Psychology of Women Quarterly, 18, 251-270.

KARASEK, R.A. (1979). Job demands, job decision latitude, and mental strain: implications for job redesign. Administrative Science Quarterly, 24, 285-308.

KARASEK, R.A. \& THEORELL, T. (1990). Healthy work: Stress, productivity, and the reconstruction of working life. New York: Basic Books.

Kelloway, E.K., GotTlieb, B.H. \& Barham, L. (1999). The source, nature, and direction of work and family conflict: a longitudinal investigation. Fournal of Occupational Health Psychology, 4, 337-346.

KINNUNEN, U. \& MAUNO, S. (1998). Antecedents and outcomes of work-family conflict among employed women and men in Finland. Human Relations, 51, 157-177.

KLINE, P. (1993). The handbook of psychological testing. London: Routledge.

Kossek, E. \& Oseki, C. (1998). Work-family conflict, policies, and the job-life satisfaction relationship: a review and directions for organizational behavior-human resources research. Fournal of Applied Psychology, 83, 139-149.

Lewis, S., Kagan, C. and Heaton, P. (2000) Dual earner parents with disabled children. Family patterns for working and caring. Fournal of Family Issues, 21(8), 1031-1060.

Lu, L. (1994). University transition: major and minor life stressors, personality characteristics and mental health. Psychology and Medicine, 24, 81-87.

Lundberg, U., MARDberg, B. \& Frankenhaeuser, M. (1994). The total workload of male and female white collar workers as related to age, occupational level, and number of children. Scandinavian fournal of Psychology, 35, 315-327.

Moyle, P. (1995). The role of negative affectivity in the stress process: tests of alternative models. Fournal of Organizational Behavior, 16, 647-668.

Negrey, C. (1993). Gender, time and reduced work. Albany: State University of New York Press.

NooR, N.M. (1995). Work and family roles in relation to women's well-being: a longitudinal study. British Fournal of Social Psychology, 34, 87-106.

Noor, N.M. (1996). Some demographic, personality and role variables as correlates of women's well-being. Sex Roles, 34, 603-620.

Noor, N.M. (1997). Work and family roles in relation to women's well-being: the role of negative affectivity. Personality and Individual Differences, 23, 487-499.

Parasuraman, S., Purohit, Y.S., Godshalk, V.M. \& Beutell, N.J. (1996). Work and family variables, entrepreneurial career success, and psychological well-being. Fournal of Vocational Behavior, 48, 275-300.

Parkes, K.R. (1989). Personal control in an occupational context, in S.L. SAUTER, J.J. HurRelL \& C.L. CoOper (Eds.), fob control and worker health. Chichester: Wiley. 
PARKES, K.R. (1994). Personality and coping as moderators of work stress processes: models, methods and measures. Work and Stress, 8, 110-129.

Perrewe, P.L., Hochwarter, W.A. \& Kiewitz, C. (1999). Value attainment: an explanation for the negative effects of work-family conflict on job and life satisfaction. Fournal of Occupational Health Psychology, 4, 318-326.

Rapoport, R., Bailyn, L., Fletcher, J. \& PrUitT, B. (2002) Work-life balance: advances in gender equity and workplace performance. San Francisco, CA: Wiley.

Roskies, E. \& Lazarus, R.S. (1980). Coping theory and the teaching of coping skills, in P.O. DAVIDSON \& F.M. DAvidson (Eds.), Behavioral medicine: changing health and life style. New York: Brunner/Marzel.

Ross, C.E. \& Huber, J. (1985). Hardship and depression. fournal of Health and Social Behavior, 26, 77-91.

STACK, S. \& Eshleman, J.R. (1998). Marital status and happiness: a 17-nation study. Fournal of Marriage and the Family, 60, 527-536.

STEWART, W. \& BARLING, J. (1996). Fathers' work experiences effect children's behaviors via job-related affect and parenting behaviors. Fournal of Organizational Behavior, 17, 221-232.

Thomas, L.T. \& GansTER, D.C. (1995). Impact of family-supportive work variables on workfamily conflict and strain: A control perspective. Fournal of Applied Psychology, 80, 6-15.

Watson, D. \& ClaRK, L.A. (1984). Negative affectivity: the disposition to experience aversive emotional states. Psychological Bulletin, 96, 465-490.

Windebank, J. (2001) Dual-earner couples in Britain and France: gender divisions of domestic labour and parenting work in different welfare states. Work Employment and Society, 15(2), 269-290.

\section{Biographical note}

Noraini M. Noor, D.Phil., is Associate Professor in Psychology at the International Islamic University, Malaysia. She did her undergraduate studies at Monash University (B.Sc.) and the University of Tasmania (B.Sc.Hons) in Australia, and postgraduate studies at the University of Canterbury in New Zealand (M.Sc.) and the University of Oxford in the UK (D.Phil.). Her areas of interest include issues relating to women's work and family roles, mental health, work stress, individual differences and workplace policies. 

Copyright of Community, Work \& Family is the property of Taylor \& Francis Ltd. The copyright in an individual article may be maintained by the author in certain cases. Content may not be copied or emailed to multiple sites or posted to a listserv without the copyright holder's express written permission. However, users may print, download, or email articles for individual use. 